\title{
FPS Wildlife Film Library
}

Unless otherwise stated all films are $\mathrm{I} 6 \mathrm{~mm}$. in colour with sound track, and the handling charge is $f I$ each to cover postage, packing and repairs. New films are starred. To book a film please write to the Films Officer, Fauna Preservation Society, c/o Zoological Society, Regent's Park, London NWr.

*The Seals of Macquarie Island. Elephant and fur seals. I2 minutes. Charge, $£$ I ros.

*Penguins of Macquarie Island. King, gentoo, rockhopper and royal penguins. I3 minutes. Charge, $f \mathrm{r}$ ros.

*The Mallee Fowl. The remarkable nesting story of a 'mound-builder'. Ir minutes. Charge, $f$ I Ios.

The three excellent short CSIRO films from Australia (above) together make a good film show (see page I60). The charge for the three booked together is $f 4$.

Le Aye Aye de Madagascar, by J. J. Petter. Black and white, French commentary, 22 minutes. Presented by the Service du Film de Recherche Scientifique.

The Silent Watcher, by Eric Ashby, commentary by Peter Scott. Badgers, deer and foxes in the New Forest. Black and white, 35 minutes. Charge EI ros.

Escape to Samburu. Wildlife of a reserve in Northern Kenya. 40 minutes. Presented by the Munitalp Foundation.

Lake Wilderness. Wildlife of St. Lucia Lakes. 20 minutes, and

To Catch a Rhino. 20 minutes; South African Tourist Corporation.

The African Lion, by A. I. M. Hepburn. Taken in the Kruger National Park. Magnetic sound track. 12 minutes.

The Swallowtail Butterfly. The complete life story. 25 minutes.

Nairobi National Park, by Hugh Cressy-Hall. 20 minutes.

A Million Flamingos, by Hugh Cressy-Hall. 12 minutes.

Wildlife in Trust, by Gordon Maclean. The work of a Naturalists' Trust (Berks, Bucks and Oxon). 25 minutes.

South Africa's Animal Kingdom. 20 minutes. S.A. Tourist Corporation.

Wildlife in Danger. Commentary by Peter Scott. 21 minutes.

The Rain Forest, by Tom and Barbara Harrisson. Mainly about orang utans. Black and white, 27 minutes.

Wild Life in Uganda. I2 minutes.

Down in the Forest. Kangaroos. 6 minutes.

Kaziranga Sanctuary, Assam. Two films, 12 and 20 minutes respectively. Birds of East and Central Africa. 45 minutes.

Southern Rhodesia Wild Life. 45 minutes.

Conserving a Heritage. Good shots of whooping cranes. US oil company's propaganda film on how it protects wildlife. I6 minutes.

\section{Silent Films with Captions}

Ceylon Wildlife, by C. E. Norris. Written commentary.

Operation Oryx, by Michael Woodford. The FPS expedition. Black and white, 30 minutes.

The African Elephant. ro minutes.

Wild Life in Southern Rhodesia. Commentary. 15 minutes.

Wild Animals in the Indian Jungle. 20 minutes. 


\section{Printed in Great Britain by \\ Alden \& Mowbray Ltd \\ at the Alden Press, Oxford}

